\title{
Problems of capital structure: the case of Latvia
}

\begin{abstract}
Capital is a limited resource in an economy and it is important that its use is costeffective. It is important that capital raising in enterprises and industries is rational and allows an appropriate capital structure with the highest returns, thus providing further sustainable economic development. Research into capital structure started several decades ago but, up to now, the precise identification of a company's optimal capital structure and the factors that determine the most appropriate capital structure are issues that have not been resolved. Based on research, the authors conclude, that during the 1995-2008 period, the total assets of Latvian enterprises have increased considerably, while the capital structure of Latvian enterprises has changed noticeably. Under the current changing economic conditions, one of the most important issues of decisions on capital structure is the adequate level of debt. Despite the use of debt increasing the financial risk of the enterprise, the raising of debt capital is crucial for the survival and development of the real sector of the economy and thus for the national economy as a whole.
\end{abstract}

Keywords: bank loans, capital structure, debt capital, equity, raising capital

Introduction

Capital, both real and financial, is essential for every enterprise. Real or economic capital, like machinery or equipment, is needed for the production of goods and services, while financial capital means the funds that are necessary to acquire real capital and to ensure investment and the operations of enterprises. Thus, raising financial capital is important for the sustainable development of any enterprise, as well as from the point of view of the national economy for further sustainable economic development.

Every company has, sooner or later, to take financial capital-raising decisions, choosing between debt and equity financing. The choice of the appropriate type of financing and optimal capital structure is a topical issue for enterprises. However, there is no universal solution that can be applicable in every case: financing decisions and capital structure decisions depend on numerous factors.

The use of each means of capital-raising has numerous advantages and disadvantages. So, raising equity capital by going public facilitates the raising of large volumes of capital that can be used for different purposes, and does not imply an obligation to repay the funds. However, issuing stock means more publicity, while reputation issues become more topical through market pressure and favourability. Moreover, equity investors become part-owners of the enterprise, thus having, to some extent, the possibility of controlling it. Raising equity is usually rather expensive, along with the greater complexity and relatively high costs of administration and complying with regulatory requirements. 
On the other hand, raising debt capital trough bond issues or bank loans is cheaper. Moreover, interest on debt is tax-deductible, meaning that debt has tax benefits (tax shield). However, raising debt capital implies an obligation to repay the funds acquired according to the prospectus or loan agreement. Thus, the repayment of debt can cause enterprises cash flow problems. At the same time, the enterprise is entitled to the repayment of the debt principal as well as interest according to the agreement, while the lender does not have any further claim on the future profits of the enterprise. Moreover, an increased use of debt capital, or financial leverage, increases the expected return on equity (ROE), but it also causes an increase of risk and the cost both of equity and debt capital.

Thus, an in-depth analysis of financing alternatives should be made to find a proper balance between equity and debt capital, taking into account the amount of capital needed; the time aspect (when and for how long capital is needed); and other factors.

The key problem for financial management is considered to be the development of an efficient structure for the sources of funding so as to provide for the successful funding of the necessary expenses and to ensure the desired level of income. The efficiency of the selected capital structure is directly related to the successful performance of the enterprise.

Research into capital structure was started several decades ago. Nobel prize winners Franco Modigliani and Merton Miller were the first to theorise this issue (1958). The Modigliani-Miller theorem, assuming the absence of taxes, bankruptcy costs and asymmetric information states that, in an efficient market, the market value of company does not depend on its capital structure [12: 397]. These results are controversial, but can be true under particular conditions.

The outcome of further research has been numerous studies analysing different aspects of capital structure and capital raising (e.g. Kraus and Litzenberger, 1973; Jensen and Meckling, 1976; De Angelo and Masulis, 1980; Green, 1984; Myers and Majluf, 1984; Brander and Lewis, 1986; Ghosh, Nag and Sirmans, 1999; Murray, 2007; etc.).

The problem of the choice of capital-raising alternatives and capital structure is also topical in Latvia. There is a number of reasons for this. First, there is practically no indepth research on the capital structure of Latvian enterprises. Second, there is no empirical study that would prove (or deny) the use of one or another capital structure theory among Latvian enterprises. And, third, the until recently booming lending to the real sector of the economy has influenced the capital structure of enterprises. Enterprises used to raise debt capital very actively, but there has been no sufficiently deep analysis made of the influence of the increased use of debt capital on enterprise performance and its advantages for enterprises.

Based on an analysis of the capital structure of Latvian enterprises, the goal of this article is to make conclusions on the effectiveness of the use of debt and equity capital, as well as to find possible reasons for the trends in capital structure changes. 
Analysis of the capital structure of Latvian enterprises

The regularities of economic theory, as well as empirical evidence about enterprise capital dynamics, suggest that, along with the increasingly considerable development of business, the share of debt capital in total capital is rising. A similar trend has also been observed in Latvia. Over the fourteen years of the research period, business capital structure in Latvia has changed in accordance with the rules of the market economy. Thus, at the beginning of the period, in 1995, total capital was dominated by equity capital; however, the situation is now vice versa - total capital structure is dominated by debt capital. This can be explained in that, over all these years, i.e. in the period between 1995 and 2008, debt capital was raised much more quickly than equity capital in the funding of business (see Table 1).

Table 1 - The dynamics of equity and debt capital in Latvian enterprises, 1995-2008 $[1-11 ; 13,1]^{1}$

\begin{tabular}{|c|c|c|c|c|c|c|c|c|c|}
\hline \multirow{2}{*}{ Year } & \multicolumn{3}{|c}{ Equity capital } & \multicolumn{5}{c|}{ Debt capital } \\
\cline { 5 - 11 } & \multicolumn{2}{|c|}{$\begin{array}{c}\text { mIn. } \\
\text { LVL to }\end{array}$} & $\begin{array}{c}\text { \% to } \\
\text { previous } \\
\text { year }\end{array}$ & $\begin{array}{c}\text { mIn. } \\
\text { LVL }\end{array}$ & $\begin{array}{c}\text { \% to } \\
\mathbf{1 9 9 5}\end{array}$ & $\begin{array}{c}\text { \% to } \\
\text { previous } \\
\text { year }\end{array}$ & $\begin{array}{c}\text { mIn. } \\
\text { LVL }\end{array}$ & $\begin{array}{c}\text { \% to } \\
\text { debt } \\
\text { capital }\end{array}$ & $\begin{array}{c}\text { \% to } \\
\text { previous } \\
\text { year }\end{array}$ \\
\hline 1995 & 2362.6 & 100.0 & - & 1826.8 & 100.0 & - & 292.5 & 16.0 & - \\
\hline 1996 & 2329.1 & 98.6 & 98.6 & 2214.5 & 121.2 & 121.2 & 277.4 & 12.5 & 94.8 \\
\hline 1997 & 2850.4 & 120.6 & 122.4 & 2695.4 & 147.5 & 121.7 & 435.4 & 16.2 & 157.0 \\
\hline 1998 & 3391.3 & 143.5 & 119.0 & 3438.7 & 188.2 & 127.6 & 659.8 & 19.2 & 151.5 \\
\hline 1999 & 3491.5 & 147.8 & 103.0 & 3742.8 & 204.9 & 108.8 & 685.0 & 18.3 & 103.8 \\
\hline 2000 & 3571.3 & 151.2 & 102.3 & 4472.8 & 244.8 & 119.5 & 932.1 & 20.8 & 136.1 \\
\hline 2001 & 3827.9 & 162.0 & 107.2 & 4923.5 & 269.5 & 110.1 & 1205.2 & 24.5 & 129.3 \\
\hline 2002 & 4121.0 & 174.4 & 107.7 & 5331.1 & 291.8 & 108.3 & 1440.3 & 27.0 & 119.5 \\
\hline 2003 & 4849.8 & 205.3 & 117.7 & 6346.2 & 347.4 & 119.0 & 1854.9 & 29.2 & 128.8 \\
\hline 2004 & 5524.3 & 233.8 & 113.9 & 7969.1 & 436.2 & 125.6 & 2160.0 & 27.1 & 116.4 \\
\hline 2005 & 6008.9 & 254.3 & 108.8 & 11315 & 619.4 & 142.0 & 3311.5 & 29.3 & 153.3 \\
\hline 2006 & 7362.1 & 311.6 & 122.5 & 15720 & 860.5 & 138.9 & 4920.8 & 31.3 & 148.6 \\
\hline 2007 & 9756.4 & 413.0 & 132.5 & 22183 & 1214.3 & 141.1 & 7372.7 & 33.2 & 149.8 \\
\hline 2008 & 10390 & 439.8 & 106.5 & 25362 & 1388.3 & 114.3 & 8961.4 & 35.3 & 121.5 \\
\hline & & & & & & & & & \\
\hline
\end{tabular}

Analysing Table 1, it can be seen that, in 2008, equity capital had increased fourfold compared to the beginning of the research period; however, the dynamics of debt

1 Under the condition that accruals are added to debt capital. 
capital in use was even faster - in 2008, compared to 1995, debt capital had grown 13.9 times. The diverse growth dynamics of equity and debt capital has also changed their share in total capital (see Table 2).

Table 2 - The share of equity and debt capital in the total capital of Latvian enterprises, 1995-2008 [1-10; 13, 1]

\begin{tabular}{|l|c|c|}
\hline Year & $\begin{array}{c}\text { Share of equity capital in total } \\
\text { capital, } \%\end{array}$ & $\begin{array}{c}\text { Share of debt capital in total capital, } \\
\mathbf{\%}\end{array}$ \\
\hline 1995 & 56.4 & 43.6 \\
\hline 1996 & 51.3 & 48.7 \\
\hline 1997 & 51.4 & 48.6 \\
\hline 1998 & 49.7 & 50.3 \\
\hline 1999 & 48.3 & 51.7 \\
\hline 2000 & 44.4 & 55.6 \\
\hline 2001 & 43.7 & 56.3 \\
\hline 2002 & 43.6 & 56.4 \\
\hline 2003 & 43.3 & 56.7 \\
\hline 2004 & 40.9 & 59.1 \\
\hline 2005 & 34.7 & 65.3 \\
\hline 2006 & 31.9 & 68.1 \\
\hline 2007 & 30.5 & 69.5 \\
\hline 2008 & 29.1 & 70.9 \\
\hline
\end{tabular}

According to the data in Table 2, in the period between 1995 and 2008 in Latvia, the share of debt capital in total capital increased from $43.6 \%$ to $70.9 \%$ on account of the decrease in the share of equity capital - in the period under research, it fell from $56.4 \%$ to $29.1 \%$.

Analysis of the growing share of debt capital in the total capital of Latvian enterprises

During the 1995-2008 period, the total assets of Latvian enterprises increased considerably, mainly as a result of the increase in debt capital. The share of bank loans in the total capital of enterprises has also increased considerably. Consequently, the specific weight of bank loans since 2000 has come to constitute more than $10 \%$ and, since 2006 , more than $20 \%$ of total capital (Chart 1). Furthermore, during the period under analysis, the share of bank loans in debt capital increased more than 2.2 times; in the last three years, comprising more than one-third of the debt capital of Latvian enterprises. 


\section{Chart 1 - Bank loans as a percentage of total capital [14]}

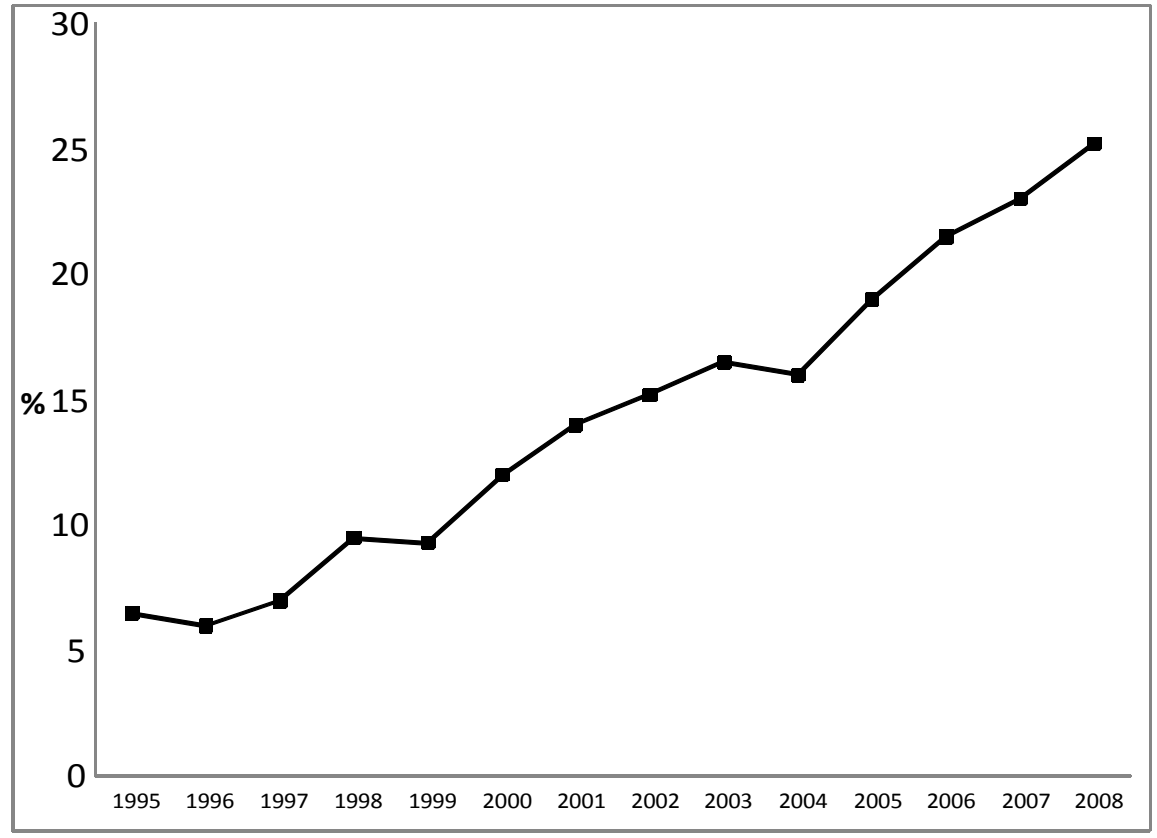

The rapid growth of the share of loans in enterprise funding was determined by several factors.

First, the small volume of loans issued by banks in the middle of the 1990s. After the accession of Latvia to the EU in 2004, the growth rate of loan volumes exceeded $45 \%$ per year. During the period under analysis, the share of lending operations in the total assets of Latvian commercial banks increased significantly (see Chart 2): Latvian commercial banks invested more than one-half of their resources in lending operations, considering these to be most profitable. Indeed, at the end of 2008, the interest income on loans issued to non-banks accounted for $61.3 \%$ of the aggregate income of commercial banks [15].

Evaluating the structure of bank loan portfolios, it has to be mentioned that more than $50 \%$ of loans have been granted to corporate customers (loans to residents excluding loans to central/local governments, households and non-profit organisations servicing households and transit loans). This is positive, since loans to enterprises are mainly used for production and the creation of value added, i.e. towards the development of the national economy, thus fostering economic growth. Over fourteen years, the volume of loans issued by banks grew from 292.5 million LVL to 9.0 billion LVL and, at the end of 2008, accounted for $35.3 \%$ of the total debt capital of Latvian enterprises. 
Chart 2 - Assets and loans of Latvian commercial banks, 2001-2006 (end of period, million LVL) [15]

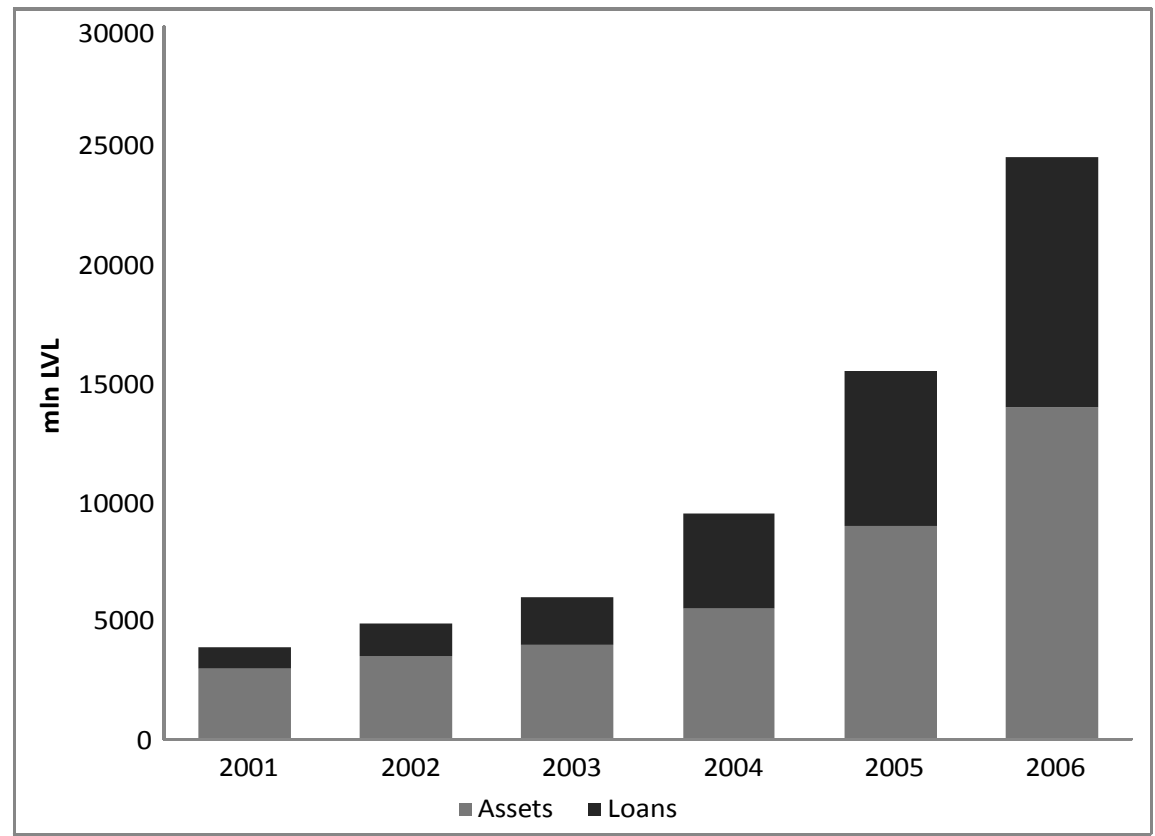

Thus, successful economic development and intensified competition between the banks in the area of lending has resulted in the better availability of loans for Latvian enterprises.

Second, the loan price (interest rate) is one of the most substantial factors that determined the rapid growth of bank loans in enterprise financing. During the 1995 to 2004 period, the weighted average interest rate of issued loans in Latvian lats has decreased significantly, from $27.4 \%$ for long-term loans in 1995 to $7.5 \%$ in 2003 (see Chart 3). 
Chart 3 - Weighted average interest rate of loans issued in LVL by Latvian banks, 1995-2008 (\%) [13]

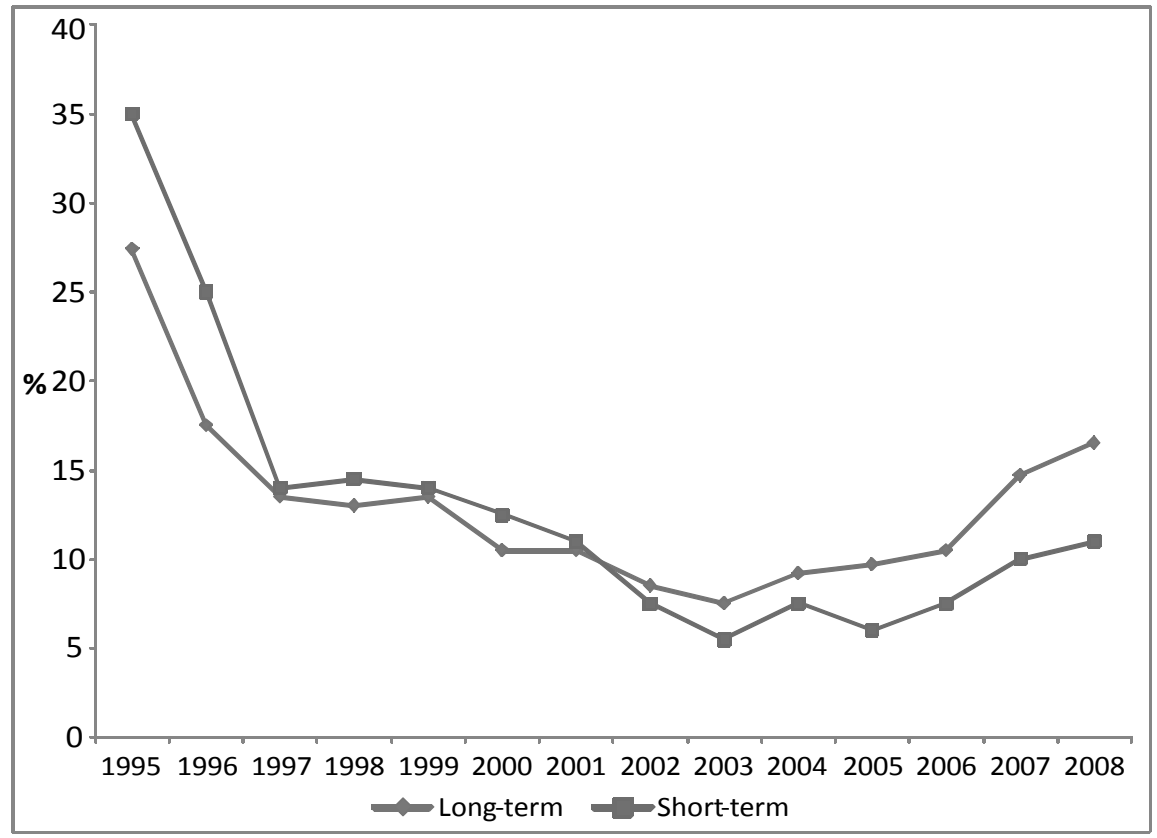

The majority of loans in Latvia are, however, denominated in foreign currencies. At the end of 2003, loans issued to Latvian residents in foreign currencies constituted around $56 \%$ of total loans (35\% in US dollars, $19 \%$ in Euros, $2 \%$ in other currencies). In 2008 , the share of loans issued to Latvian residents in foreign currencies increased to more than $88 \%$ of the total volume of loans.

One of the main reasons for these changes are the lower interest rates for loans denominated in foreign currencies caused by the favourable situation on the international markets (see Chart 4). The decrease in bank loan interest rates made loans economically more attractive, thus providing for the attractiveness of borrowing even at a very small rate of return on enterprise capital. However, along with declining liquidity in global markets and increasing interest rates, the risk that the interest rates payable exceed enterprise capital return ratios also rises. This, in turn, burdens the further development of enterprises and its feasibility. 


\section{Chart 4 - 6-month US dollar LIBOR rates, 2001-2008 [13]}

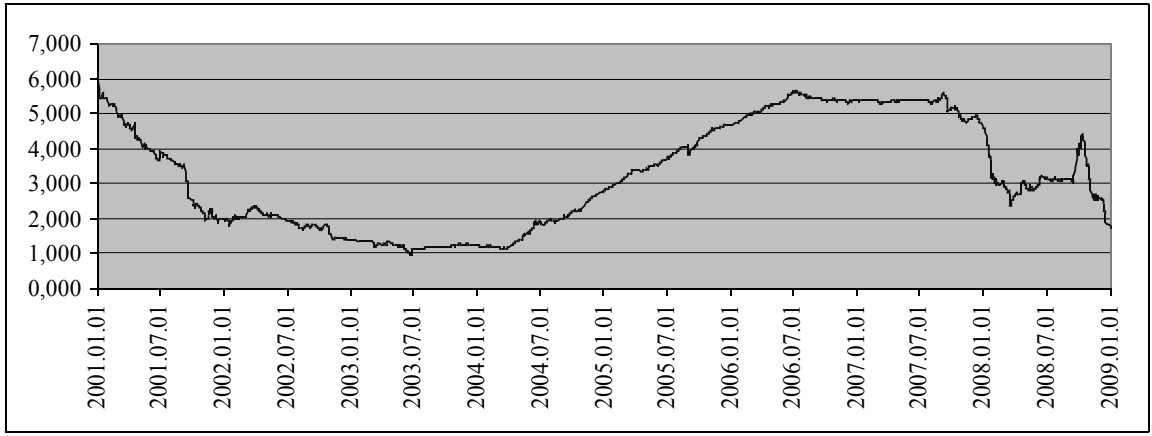

Moreover, the loan products offered by banks were very similar, with the main difference in interest rates making this the crucial factor in bank competition. The result was that, under conditions of tough competition, banks offered their customers loans at very low interest rates, even granting loans with a minimal profit margin. Besides, several banks with access to considerable amounts of cheap financial resources (e.g. from a parent bank) offered loans to some of their customers at prices even lower than the resource price in the market, thus increasing their market share in the specific sector and forcing out competitors.

Third, the rapid growth of debt capital was also fostered by market developments, i.e. the availability of loans and the increased supply of funding services and instruments of financial settlement. Until now, bonds as an instrument of capital raising has not been popular among Latvian enterprises, mainly due to the widely-available and relatively cheap bank loans. To attract foreign investors, a bond issue has to have a rating and be in a sufficient volume; however, small bond issues can access Latvian investors and, consequently, their range is limited. According to the experts, only the top 200 largest Latvian enterprises could consider capital raising via the issue of bonds [16]. The result is that the issue of bonds is not an appropriate capital-raising source for small and medium enterprises (SMEs). According to statistics, SMEs account for $99 \%$ of all enterprises in Latvia and create more than $60 \%$ of national GDP and, altogether, employ approximately $70 \%$ of the labour force. Thus, bank loans are of major significance for the business and growth of SMEs and, thus, for the growth of the economy as a whole.

Fourth, the significant increase of debt capital in the capital structure of Latvian enterprises can be explained by the relative simplicity of the provisions of loans by commercial banks. Consequently, it was easier for an enterprise to raise capital by obtaining a bank loan compared to the necessity of searching for potential investors who could provide equity capital. Besides, debt capital owners normally do not interfere in the operational management of an enterprise, although equity capital owners may well want to take control of it.

Thus, one of the most important factors that has determined the capital structure of Latvian enterprises in the period under analysis is bank lending and loan availability, 
resulting in the substantial growth of the share of debt capital in the total capital of enterprises.

\section{Analysis of the effectiveness of the use of debt capital}

In theoretical terms, the growth of the share of debt capital has a positive effect on the process of business development if the enterprise disposes of a sufficient amount of borrowed funds and at a lower price than equity funds. The use of debt capital also enhances the maximisation of the owners' wealth under the condition that the return on assets exceeds the average interest rate on debt.

Considering the previously analysed trends in capital structure, it is important to determine if enterprise decisions on raising debt capital have been economically grounded. This means whether they have been based on an effective use of the financial leverage effect, or whether enterprises have been guided by the necessity of capital to ensure their further operations and by the availability of funds in the financial market, without paying attention to the possibility that the future costs of debt capital will cost more than the enterprise can earn. To find this out, the return on equity and total capital (total assets) can be calculated and analysed. The return on total capital is determined using a calculation method that relates the reporting year profit after tax and the interest paid on debt capital to the average capital (assets) employed in the period. The return on equity, however, is referred to as the ratio between net profits and the average value of equity.

The calculations made as regards the return on assets and equity in Latvia are summarised in Table 3.

Table 3 - The return on total capital and equity capital in Latvian enterprises, 1995-2008 [1-11; 13]

\begin{tabular}{|c|c|c|}
\hline Year & Return on capital, \% & Return on equity capital, \% \\
\hline 1995 & 1.3 & -1.2 \\
\hline 1996 & 0.9 & -2.1 \\
\hline 1997 & 4.8 & 5.6 \\
\hline 1998 & 4.0 & 3.4 \\
\hline 1999 & 3.5 & 2.4 \\
\hline 2000 & 3.6 & 2.7 \\
\hline 2001 & 4.9 & 5.9 \\
\hline 2002 & 4.7 & 5.7 \\
\hline 2003 & 5.5 & 7.9 \\
\hline 2004 & 7.3 & 13.2 \\
\hline 2005 & 6.3 & 12.6 \\
\hline 2006 & 8.7 & 21.4 \\
\hline
\end{tabular}




\begin{tabular}{|c|c|c|}
\hline Year & Return on capital, $\%$ & Return on equity capital, $\%$ \\
\hline 2007 & 8.0 & 19.7 \\
\hline 2008 & 3.2 & 4.8 \\
\hline
\end{tabular}

Analysing the data in Table 3, it can be concluded that, in the period under research, the dynamics of the profitability ratios were rather irregular although there was a growth trend, at least until 2006. In the period between 1995 and 2008, the return on equity fluctuated in a range from $-2.1 \%$ to $21.4 \%$; however, the return on assets fluctuated between the margins of $0.9 \%$ to $8.7 \%$. Essentially, the return on assets shows the profit the enterprise has gained per each 1 LVL of assets. The return on equity, in its turn, allows a determination of the efficiency of the use of the capital invested by the enterprise owners. From the owners' point of view, this is the most important among the profitability indicators since it shows how much profit has been acquired per each LVL invested by the owners of the enterprise.

The more intensive involvement of debt capital in the funding of Latvian enterprises was economically justified in 1997, as well as in the period from 2001 to 2008, when the return on equity exceeded that of total capital. Basically, this means that, in these years, enterprise owners profited on the account of creditors. However, in 2007 and particularly in 2008, the profit earned by enterprises started to fall considerably. This should have been perceived as a warning sign of the likely beginning of economic recession.

The periods when the return on equity was lower than the return on total capital suggest that debt capital has been so expensive that enterprises have had to pay interest not only from the profit earned by debt capital, but also to channel for this purpose at least a part of the profit earned by equity capital. At the beginning of the research period - in 1995 and 1996 - the return on equity was even negative, which means that entrepreneurs have incurred losses: in this case, speaking of the efficient use of capital is out of the question.

However, there is still the possibility that the use of debt capital was economically justified also in the period up to 2001, as Latvian enterprises tended to see a reduction in reportable profits. Larger actual profits would increase profitability, as well as change the proportion between the return on assets and on equity capital in favour of the latter.

On the other hand, when analysing the return on enterprise assets and equity capital in comparison to the weighted average interest rates on loans issued by commercial banks in LVL, we might conclude that a dangerous trend has been apparent since 2006 - a decrease in the return on assets and equity in relation to average weighted rates (see Chart 5). A similar trend can also be seen from a comparison of the return on assets and equity with the average weighted rates of loans issued by banks denominated both in Euros and in US dollars. 
Chart 5 - Weighted average interest rates of loans issued in LVL by Latvian banks, ROA and ROE, 1995-2008 $(\%)^{2}[13,14]$

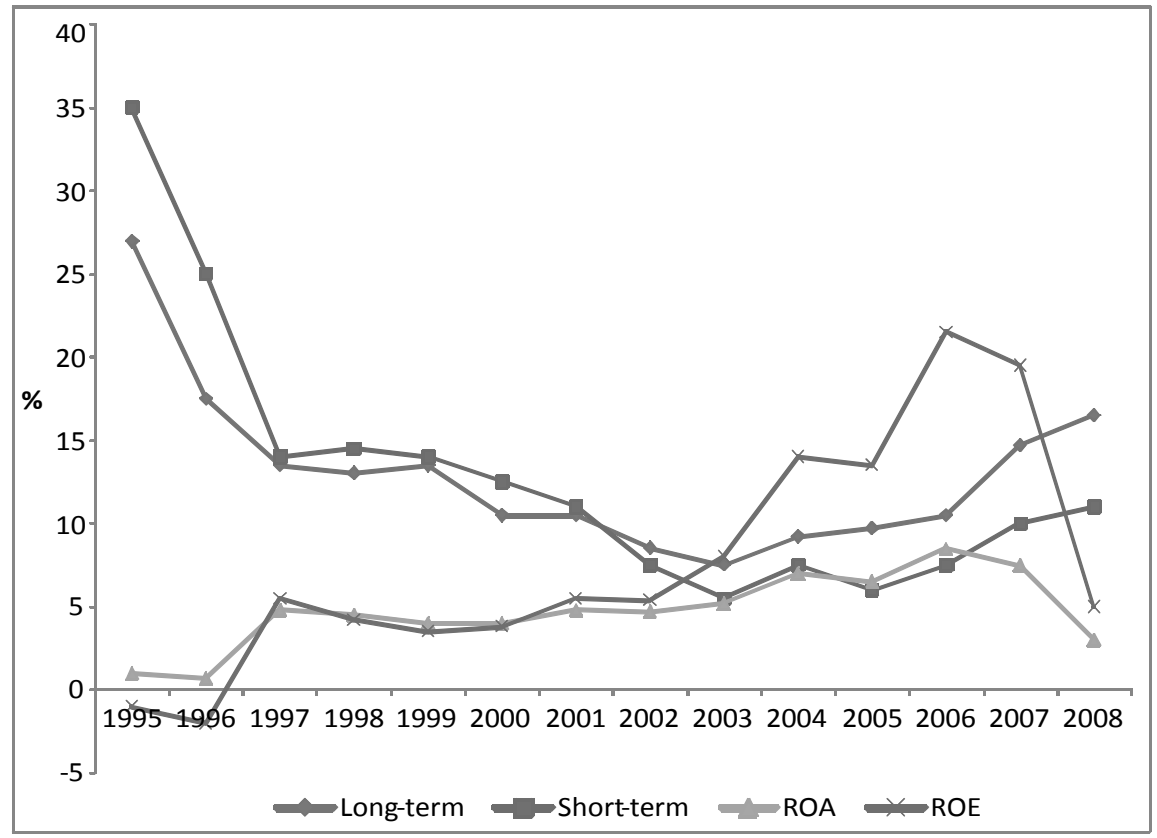

On the one hand, the use of debt in the capital structure normally leads to a higher return on equity, as the use of debt capital is relatively cheap and interest payments are tax deductible. However, the benefits of financial leverage vanish if the cost of debt capital exceeds the return on assets. We might also draw special attention to weighted average interest rates (in all currencies) having exceeded the return on the assets of Latvian enterprises since 2007. This increases the default risk of enterprises and renders ineffective the use of debt capital for enterprise financing since, if the return on assets is lower than the cost of debt capital, the return on equity is degraded by the use of debt capital.

Analysing the capital structure of Latvian enterprises, we can see that, during the research period, bank loans were an important source of capital. Under the conditions of the current economic recession, lending and the accessibility of loans represent one of the most important factors in stimulating the development of the national economy.

First, the result of the current economic conditions is that enterprises lack current assets for the continuation of their economic activity which leads to a short-term liquidity problem. This problem can be easily resolved where enterprises have access to bank loans for increasing their current assets.

2 The loan rates are not tax deductible. 
Second, in order to overcome the recession and provide for the long-term development of the national economy, it is necessary to continue long-term lending to enterprises, paying particular attention to industries with export potential. This would facilitate an increase in enterprise productivity and efficiency, as well as improve the quality of product. In the conditions of economic recession, this explains the importance of bank support to enterprises in the form of short-term and long-term loans.

However, an adequate capital structure is critical for the sustainable development of enterprises. The deterioration in the economic situation has, to a large extent, affected the ability of enterprises to repay the loans they have received. Industries facing particular problems in loan repayment are these: the mining industry and opencast mining; real estate operations; the hospitality industry; and health and social care. This confirms the need for the creation of an adequate capital structure.

\section{Conclusions}

Based on the problems identified and analysed in this article, we might draw the following conclusions and suggestions:

- the research results provide a clear reflection of the gradual growth of the Latvian economy up to the beginning of the recession in 2008, as well as of the effects of the expansive loan policy of commercial banks when enterprises were mostly guided by the accessibility of funds in the market, disregarding the capacity of businesses to earn in the future

- when opting for debt capital financing, enterprises must consider several sources of debt capital. If the interest rates offered by banks are rising, or are not attractive to the borrower, small and medium enterprises must look for other options to raise capital. However, large enterprises with steady previous performance may be able to consider issuing bonds

- the share of debt capital in the aggregate business capital structure in Latvia is growing, so the majority of enterprises should carefully monitor the risks arising from the use of debt capital. Empirical evidence from the period of the research suggests that an excessive share of debt capital may lead to enterprises paying interest for the use of debt capital not only out of their profits; in the worst case, paying interest may lead to enterprises selling their assets, which can cause serious disturbances in enterprise business operations.

\section{References}

Statistiskais biḷetens (1996) Uzñèmumu (uzņēmējsabiedrību) finansiālās darbības pamatrādītāji 1995. Gadā. Rīga: Latvijas Republikas Valsts statistikas komiteja.

Uzņèmumu un uzn̄èmējsabiedrību finansiālās darbības radītāji 1996. gadā (veidlapu Nr.1-F gada izstrāde) Rīga: Latvijas Republikas Valsts statistikas komiteja, 1997.

Uzņēmumu (uzņēmējsabiedrību) finansiālās darbības pamatrādītāji 1997. gadā. Rīga: Latvijas Republikas Centrālā statistikas pārvalde, 1998.

Uzņēmumu (uzņēmējsabiedrību) finansiālās darbības pamatrādītāji 1998. gadā. Rīga: Latvijas Republikas Centrālā statistikas pārvalde, 1999. 
'Uzṇēmējdarbības finansiālie pamatrādītāji 1999. gadā.' Statistikas biļetens Rīga: Latvijas Republikas Centrālā statistikas pārvalde, 2000.

'Uzṇēmējdarbības finansiālie pamatrādītāji 2000. gadā.' Statistikas biḷetens Rīga: Latvijas Republikas Centrālā statistikas pārvalde, 2001.

'Uzṇēmējdarbības finansiālie pamatrādītāji 2001. gadā.' Statistikas biļetens Rīga: Latvijas Republikas Centrālā statistikas pārvalde, 2002.

'Uzṇēmējdarbības finansiālie pamatrādītāji 2002. gadā.' Statistikas biļetens Rīga: Latvijas Republikas Centrālā statistikas pārvalde, 2003.

'Uzṇēmējdarbības finansiālie pamatrādītāji 2003. gadā.' Statistikas biļetens Rīga: Latvijas Republikas Centrālā statistikas pārvalde, 2004.

'Komercdarbības finansiālie pamatrādītāji 2004. gadā.' Statistikas biļetens Rīga: Latvijas Republikas Centrālā statistikas pārvalde, 2005.

Pieprasījums 945 (procenti un aizņēmumi: 2005-2008) Latvijas Republikas Centrālā statistikas pārvalde, 2010.

Brealey, R. A, S. C. Myers and A. J. Marcus (2007) Fundamentals of Corporate Finance Boston: McGraw-Hill/Irwin.

http://www.bank.lv [last accessed 20 May 2010].

http://www.csb.gov.lv [last accessed 3 May 2010].

http://www.fktk.lv [last accessed 4 June 2010].

http://www.rfb.lv [last accessed 4 June, 2010]. 